\title{
MIB-1 proliferative activity in invasive breast cancer measured by image analysis
}

\author{
P Querzoli, G Albonico, S Ferretti, R Rinaldi, E Magri, M Indelli, I Nenci
}

\begin{abstract}
Aims-To determine cell proliferation in infiltrating breast carcinomas.

Methods-Using the MIB-1 monoclonal antibody, the proliferation index was measured in paraffin wax sections of 871 breast cancers. The MIB-1 proliferation index was compared with other markers of disease progression: size, lymph node status, histotype, oestrogen and progesterone receptor status, expression of p53 and Neu, and DNA ploidy. All parameters were measured using image analysis. In 347 tumours, the MIB-1 and Ki-67 proliferation indexes were compared. Follow up data were available for 170 cases (median 66.5 months).
\end{abstract}

Results-Of the tumours, 314 (36\%) had a high proliferation index. The MIB-1 proliferation index was correlated directly with size, nodal status, overexpression of p53 and Neu, and the DNA index; and inversely with oestrogen and progesterone receptor status. The correlation between MIB-1 and Ki-67 proliferation indexes was statistically significant. In patients with pT1 tumours, a low proliferation index correlated with a longer relapse-free interval and overall survival; node negative patients with a low proliferation index had a longer overall survival.

Conclusions-The MIB-1 proliferation index is a reliable, practical and useful method of measuring proliferative activity and is an important predictor of clinical behaviour.

(F Clin Pathol 1996;49:926-930)

Istituto di Anatomia, Istologia e Citologia Patologica, Università di Ferrara, Ferrara, Italy

P Querzoli

G Albonico

$S$ Ferretti

R Rinaldi

E Magri

I Nenci

Divisione di

Oncologia,

“Arcispedale S Anna", Ferrara, Italy

$M$ Indelli

Correspondence to:

Dr Patrizia Querzoli, Istituto di Anatomia, Istologia e Citologia Patologica,

Università di Ferrara, via

Fossato di Mortara n. 64,

44100 Ferrara, Italy.

Accepted for publication 27 June 1996 proliferation in paraffin wax embedded specimens, including antibodies directed against proliferating cell nuclear antigen (PCNA) and the Ki-S1 and MIB-1 monoclonal antibodies. $^{3-10}$ MIB-1, in particular, recognises
Ki-67 nuclear antigen, permitting the assessment of growth fraction on small tumours, formalin fixed tissue and retrospective studies on archival material.

The aim of the present study was to measure the MIB-1 proliferation index in 871 infiltrating breast carcinomas. The results were compared with other markers of prognosis: oestrogen and progesterone receptor status, overexpression of c-erbB-2/Neu and p53, the DNA index, and the $\mathrm{Ki}-67$ proliferation index. The clinical usefulness of the MIB-1 proliferation index was also evaluated in 170 patients (median follow up 66.5 months).

\section{Methods}

Paraffin wax blocks of 871 infiltrating primary breast cancers were retrieved from the archives. The clinicopathological details of the patients studied are presented in table 1 . The mean age of the patients was 61 years; 277 $(31.8 \%)$ were pre-menopausal and 507 (58.2\%) were node negative. The MIB-1 proliferation index was also compared in patients subdivided according to age: $\leq 40$ years (51 (5.9\%) patients, group 1); 41-55 years (226 (25.9\%) patients, group 2 ); and $>55$ years (594 (68.2\%) patients, group 3). Patients were staged according to the TNM staging system as follows: $342(39.3 \%)$ as stage I; $292(33.5 \%)$ as stage IIa; $151(17.4 \%)$ as stage IIb; 24 $(2.7 \%)$ as stage IIIa; and $62(7.1 \%)$ as stage IIIb. ${ }^{11}$

Follow up data were available for 170 patients, who had undergone surgery between 1985 and 1989 (median follow up 66.5 months, range $30.5-112.5$ months). The mean age of these 170 patients was 59 years; 63 (37\%) were pre-menopausal; $82(48 \%)$ were node negative; and in $100(59 \%)$ tumours were $\leq 2 \mathrm{~cm}$ at their greatest dimension. None of the patients received preoperative treatment. Node negative patients did not receive adjuvant treatment.

\section{IMMUNOSTAINING}

MIB-1

Formalin fixed, paraffin embedded sections were pretreated in a microwave oven $(4 \times 5$ minutes at $750 \mathrm{~W}$ ) and incubated with MIB-1 (Immunotech, Marseille, France), diluted 1 in 50 , for one hour.

\section{Ki-67}

Frozen sections were fixed in acetone at $-20^{\circ} \mathrm{C}$ for 10 minutes and stored at this temperature pending analysis. Sections were incubated with 
Table 1 Clinicopathological features of the 871 patients with invasive breast cancer

\begin{tabular}{ll}
\hline Clinicopathological feature & Value \\
\hline Mean age (years) & 61 \\
Menopausal status & \\
Pre-menopausal & $31.8 \%$ \\
Postmenopausal & $68.2 \%$ \\
Histological subtype & \\
Ductal & $73.9 \%$ \\
Lobular & $15.6 \%$ \\
Tubular & $3.6 \%$ \\
Mucinous & $2.2 \%$ \\
Papillary & $1.6 \%$ \\
Cribriform & $0.9 \%$ \\
Medullary & $0.6 \%$ \\
Mixed/others & $1.6 \%$ \\
Tumour size (cm) & \\
11 & $26.4 \%$ \\
1-2 & $39.3 \%$ \\
$2-5$ & $32.3 \%$ \\
$>5$ & $2 \%$ \\
Lymph node status & \\
Positive & $41.8 \%$ \\
Negative & $58.2 \%$ \\
MIB-1 PI (\%PA) (871 cases) $>13 \%$ & $36.4 \%$ \\
ER-ICA (\%PA) (841 cases) $>10 \%$ & $76.3 \%$ \\
PR-ICA (\%PA) (737 cases) $>10 \%$ & $63.4 \%$ \\
Neu (\%PA) (868 cases) $>10 \%$ & $33.2 \%$ \\
p53 (\%PA) (411 cases) $>5 \%$ & $27 \%$ \\
DNA index (267 cases) aneuploid & $80.1 \%$ \\
\hline & \\
\hline &
\end{tabular}

ER = oestrogen receptor; $\mathrm{PR}=$ progesterone receptor; $\mathrm{ICA}=$ immunocytochemical assay; $\mathrm{PI}=$ proliferation index; $\mathrm{PA}=$ positive area.

the $\mathrm{Ki}-67$ antibody (Dako, Glostrup, Denmark), diluted 1 in 250 , for 45 minutes.

Oestrogen and progesterone receptor status

Hormonal receptor status was evaluated by staining with the H222 (ER-ICA; Abbott Laboratories, Chicago, Illinois, USA) and KD68 monoclonal antibodies. Fixation and staining procedures of cryostat sections were as recommended by the manufacturer. Paraffin wax sections were stained using a Streptavidin peroxidase method (Biogenex, San Ramon, California, USA). Sections were predigested with pronase (Sigma, St Louis, Missouri, USA) at $37^{\circ} \mathrm{C}$ for nine minutes prior to staining with $\mathrm{H} 222$. For progesterone receptor, sections were dewaxed at $58^{\circ} \mathrm{C}$ for two hours and incubated with KD68 (PR-ICA; Abbott Laboratories).

\section{Immunostaining of c-erbB-2/Neu}

To detect c-erbB-2/Neu, paraffin wax sections were incubated with the Ab-1 monoclonal antibody directed against p185 (Triton Diagnostics, Alameda, California, USA), diluted 1 in 100 , for one hour.

\section{p53 immunostaining}

Microwave pretreated sections were incubated with the D07 monoclonal antibody (Dako), diluted 1 in 25 , for one hour.

Table 2 MIB-1 proliferation index (PI) in each histotype

\begin{tabular}{lc}
\hline Histotype & $M I B-1$ PI $(\% P A>13)$ \\
\hline Ductal & $41.8 \%$ \\
Lobular & $21.3 \%$ \\
Medullary & $100.0 \%$ \\
Tubular & $9.7 \%$ \\
Mucinous & $10.5 \%$ \\
Papillary & $21.4 \%$ \\
Cribriform & $12.5 \%$ \\
Other/mixed & $44.4 \%$ \\
\hline
\end{tabular}

$\mathrm{PA}=$ positive area
The MIB-1, Ki-67, Ab-1, and D07 antibodies were detected using the avidin-biotinperoxidase complex (ABC) method (Vectastain ABC kit; Vector Laboratories, Burlingame, California, USA). 3,3'Diaminobenzidine tetrahydrochloride (Sigma) was used as the chromogen; ethyl green was used for nuclear counterstaining, as described by the manufacturer (Cell Analysis Systems, San Jose, California, USA).

\section{DNA index}

Touch imprints were dried in air for one hour, fixed in $10 \%$ buffered formalin for 30 minutes and stained by the Feulgen method using a commercially available kit (Quantitative DNA stain, Cell Analysis Systems).

\section{IMAGE ANALYSIS}

The proliferation index (MIB-1/Ki-67), oestrogen and progesterone receptor status, p53, $\mathrm{Neu}$, and DNA ploidy were quantified using an image analysis system (CAS 200; Becton Dickinson, San Jose, California, USA). ${ }^{12}$ The percentage of positively stained nuclei (proliferation index, oestrogen and progesterone receptor and p53) and plasma membranes (Neu) was recorded. The use of an interactive window command allows the operator to select the fields containing infiltrating carcinoma cells and to exclude areas with non-neoplastic components. For each tumour section, at least 25 microscopic fields, including peripheral and central areas of invasive carcinoma $(40 \times$ objective), were measured. At $\geq 15$ fields of vision, the positive nuclear area (PNA) has a low SD and a stable coefficient of variation. ${ }^{13}$ For the proliferation index, at least 2000 nuclei were assessed in order to reduce the margin of error expected. ${ }^{14}$ Ten per cent of positive area was used as cut-off value for oestrogen receptor, progesterone receptor and Neu; $5 \%$ was used for $\mathrm{p} 53 ; 13 \%$ of proliferation index representing the second tertile in distribution was used as cut-off value to divide cases with a low and high proliferative activity. The cut-off values selected were similar to those used in other studies. ${ }^{12} 1516$

For DNA ploidy 200-250 neoplastic cells for each tumour imprint were analysed and compared with calibration cells, which contained a known amount of DNA. The DNA content was determined by the quantitation of the optical density of each Feulgen stained nucleus. DNA distribution histograms were generated. The DNA index (the modal peak of DNA distribution) was assumed as the index of tumour ploidy; values between 0.9 and 1.1 were considered diploid.

STATISTICAL ANALYSIS

The relations between the MIB-1 proliferation index and other pathobiological variables were investigated using non-parametric Spearman's rank correlation tests and the Mann Whitney $\mathrm{U}$ test. Follow up analysis of the relapse-free interval and overall survival was performed using the actuarial model and Lee-Desu statistics. ${ }^{17}$ Significance was set at $p<0.05$. 


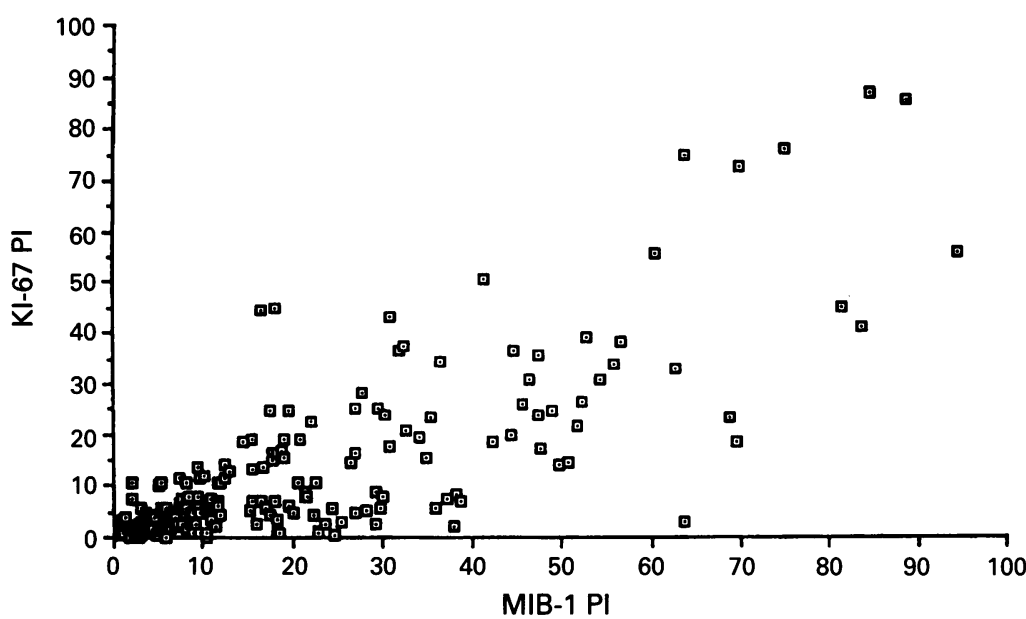

Figure 1 Correlation between MIB-1 and Ki-67 proliferation indexes (PI) (347 cases, rs $=+0.73, p<0.001$.

Table 3 Comparison between MIB-1 and Ki-67 proliferation indexes (PI)

\begin{tabular}{llcr}
\hline \multicolumn{4}{c}{$M I B-1$ PI (\%PA) } \\
\cline { 2 - 4 } & $\leq 13 \%$ & $>13 \%$ & Total \\
\hline Ki-67 (\%PA) & & & \\
$\leq 13 \%$ & 193 & 68 & 261 \\
$>13 \%$ & 2 & 84 & 86 \\
Total & 195 & 152 & 347 \\
\hline
\end{tabular}

\section{Results}

Specific MIB-1 immunostaining on paraffin wax sections was similar to that obtained with $\mathrm{Ki}-67$ on frozen sections and was localised on cell nuclei. The intensity of the nuclear staining pattern in proliferating breast carcinoma cells varied and was either uniformly granular or diffusely homogeneous, with nucleoli usually stained intensely. The staining pattern in different areas of the section was slightly heterogeneous. Moreover, the weak cytoplasmic staining observed occasionally in frozen sections on staining with $\mathrm{Ki}-67$ was absent in paraffin wax sections on staining with MIB-1.

In 871 invasive breast carcinomas the distribution of the MIB-1 proliferation index was asymmetric (skewness, +1.95 ; range, 0.01 -

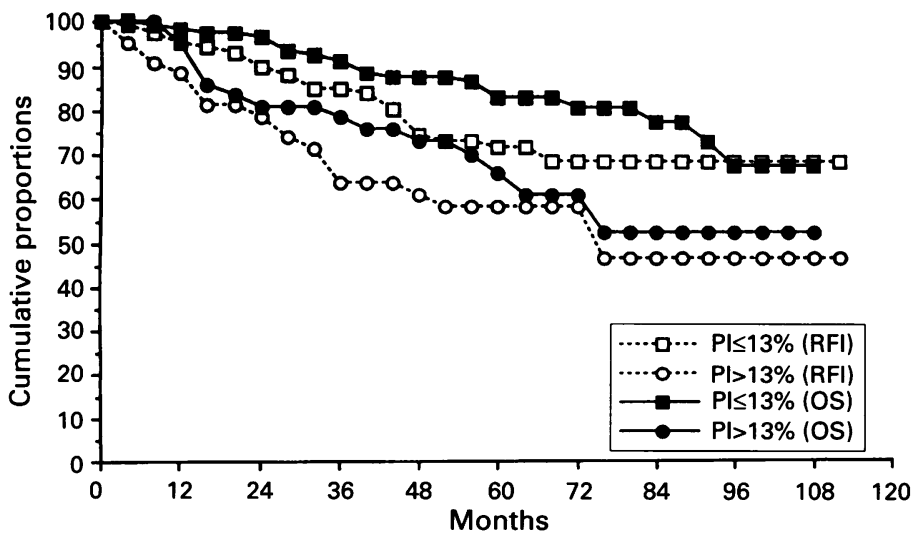

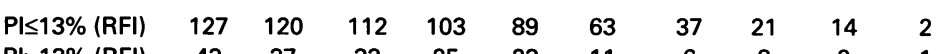

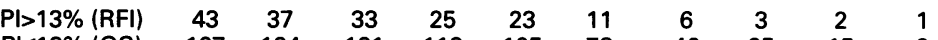
$\begin{array}{lcccccccccc}\mathrm{PI} \leq 13 \%(\mathrm{OS}) & 127 & 124 & 121 & 113 & 105 & 78 & 46 & 25 & 15 & 2 \\ \mathrm{Pl}>13 \%(\mathrm{OS}) & 43 & 40 & 34 & 31 & 28 & 15 & 8 & 4 & 2 & 1\end{array}$

Figure 2 Prognostic power of the MIB-1 proliferation index (PI). Relapse-free interval (RFI) $p=0.034$; overall survival (OS) $p=0.004$ (Lee-Desu statistic, 170 cases).
96.5\% PNA; median value, $8.42 \%$ PNA); $36.4 \%$ of tumours had a high proliferative activity. When tumours were subdivided according to histological type, $100 \%$ of medullary, $41.8 \%$ of ductal, $21.3 \%$ of lobular, and $12.5 \%$ of special types had a high proliferation index (table 2).

Specific immunostaining of hormone receptors and p53 protein was localised, as expected, on neoplastic cell nuclei; $76.3 \%$ of tumours expressed oestrogen receptor and $63.4 \%$ expressed progesterone receptor; $27 \%$ were p53 positive.

Specific immunostaining of Neu oncogene protein was present on neoplastic cell plasma membranes; $33.2 \%$ of tumours overexpressed Neu.

Eighty per cent of tumours were aneuploid. When the distribution of the MIB-1 proliferation index was assessed according to age, younger patients (group 1) had tumours with higher proliferative activities $(54.9 \%)$ than patients in groups $2 / 3(38.5 \%$ and $34 \% ; \mathrm{p}=$ 0.009).

The MIB-1 proliferation index was correlated directly with size ( $\mathrm{rs}=+0.30, \mathrm{p}<0.001)$, nodal status ( $\mathrm{rs}=+0.15, \mathrm{p}<0.001), \mathrm{p} 53$ ( $\mathrm{rs}=$ $+0.24, \mathrm{p}<0.001)$ and Neu ( $\mathrm{rs}=+0.20, \mathrm{p}<$ 0.001 ) overexpression, and DNA index ( $\mathrm{rs}=$ $+0.17, \mathrm{p}=0.026$ ); and inversely with oestrogen receptor ( $\mathrm{rs}=-0.29, \mathrm{p}<0.001)$ and progesterone receptor $(\mathrm{rs}=-0.33, \mathrm{p}<0.001)$ status. No correlation was observed with menopausal status.

Similar associations were observed when $\mathrm{Ki}-67$ immunostaining and other biopathological variables were compared: the $\mathrm{Ki}-67$ proliferation index was correlated directly with size ( $\mathrm{rs}=+0.28, \mathrm{p}<0.001$ ), p53 ( $\mathrm{rs}=+0.41, \mathrm{p}$ $<0.001$ ) and Neu (rs $=+0.19, \mathrm{p}<0.001)$ overexpression, and DNA index $(\mathrm{rs}=+0.20, \mathrm{p}$ $=0.026)$; and inversely with oestrogen receptor ( $\mathrm{rs}=-0.39, \mathrm{p}<0.001)$ and progesterone receptor ( $\mathrm{rs}=-0.39, \mathrm{p}<0.001$ ) status. No correlations were found with nodal and menopausal status.

The $\mathrm{Ki}-67$ and MIB-1 proliferation indexes were compared in 347 cases: the $\mathrm{Ki}-67$ proliferation index ranged from $0.01 \%$ to 87.7\% PNA (median 5.1\% PNA) and MIB-1 proliferation index ranged from $0.58 \%$ to 94.1\% PNA (median $11 \%$ PNA).

There was a good correlation between the MIB-1 and $\mathrm{Ki}-67$ proliferation indexes ( $\mathrm{rs}=$ +0.73 , $p<0.001$; fig 1). Discordant values were observed in 70 cases. In 68 the MIB-1 proliferation index was higher (table 3 ).

\section{CLINICAL OUTCOME}

The usefulness of the MIB-1 proliferation index as a predictor of clinical outcome was investigated in 170 cases. A significant survival advantage was demonstrated for patients whose tumours had a low proliferation index (relapse-free interval $\mathrm{p}=0.034$; overall survival $p=0.004$ ) (fig 2). Node negative patients with a low proliferation index generally survived longer $(p=0.035)$. In patients with $\mathrm{pT} 1$ tumours $(\leq 2 \mathrm{~cm})$, a low proliferation index was correlated with longer a relapse-free interval $(p$ 


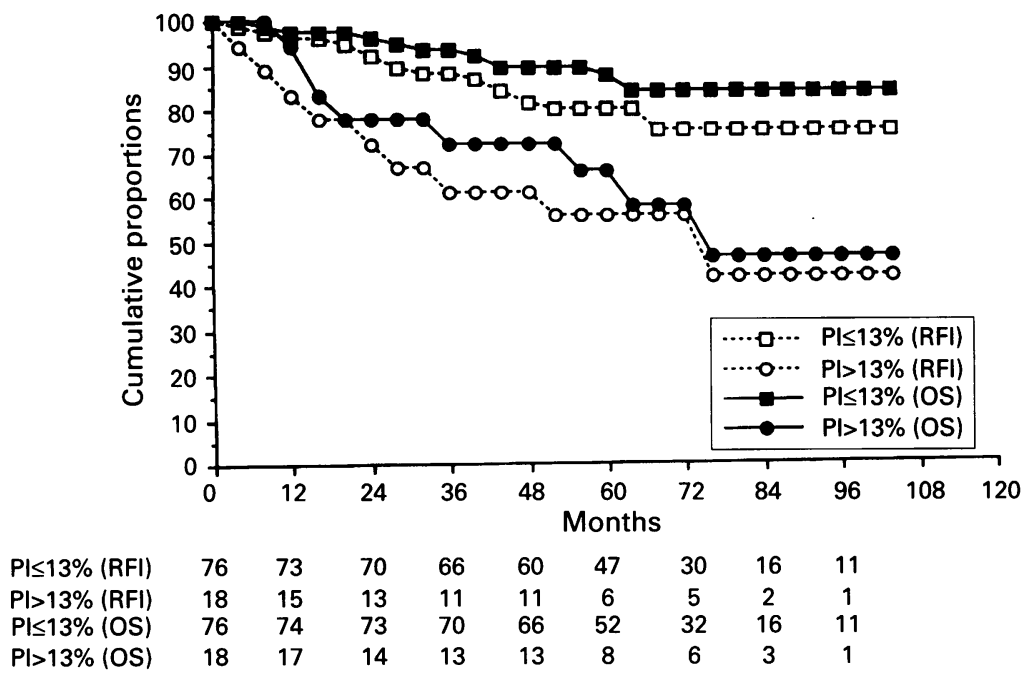

Figure 3 Prognostic power of the MIB-1 proliferation index (PI) in patients with $p T 1$ tumours. Relapse-free interval $(R F I) p=0.016$; overall survival $(O S) p=0.008$ (Lee-Desu statistic, 94 cases).

$=0.016)$ and overall survival $(\mathrm{p}=0.008)$ (fig 3). No association was found in node positive patients.

\section{Discussion}

Proliferative activity has been widely used as an important and independent prognostic factor in human cancer, including breast cancer. ${ }^{212} 1819$ Many markers of proliferation have been studied in breast cancer, including thymidine labelling, bromodeoxyuridine incorporation, flow cytometry, and more recently, immunostaining with the $\mathrm{Ki}-67$ monoclonal antibody. ${ }^{70-22}$ This antibody recognises a nuclear antigen encoded by a gene located on chromosome 10q25. ${ }^{2324}$

$\mathrm{Ki}-67$ is expressed in all phases of the cell cycle except $G_{0}$. There is increasing interest in the use of immunocytochemistry to determine the proliferative activity of tumour cells. The usefulness of the $\mathrm{Ki}-67$ proliferation index has been demonstrated in many studies, ${ }^{25-27}$ but its use is restricted to frozen tissue. However, antibodies are now available for use on paraffin wax embedded material, including the MIB-1 antibody (raised by immunising mice with recombinant $\mathrm{Ki}-67$ gene product) which recognises the $\mathrm{Ki}-67$ nuclear antigen. The use of paraffin wax embedded specimens has many advantages: morphology is preserved and immunostaining strong, permitting easier recognition of cellular features.

In the present study we verified that the MIB-1 proliferation index is a reliable, practical and useful method of measuring proliferative activity and can be used in association with other prognostic parameters (for example, oestrogen and progesterone receptor status, c-erbB-2/Neu and p53) to predict survival. Our results are in agreement with those reported by others in breast cancer and other tumour types. ${ }^{28-34}$ The discordant median values reported by us and Pinder et al ${ }^{\beta 1}$ may be because of the different clinicopathological features of the patients studied. The lack of an inverse correlation between MIB-1 proliferation index and oestrogen receptor status reported by Pinder et al could be related to the different methods used (dextran coated charcoal $v$ immunocytochemistry).

A frequent objection to the use of immunocytochemistry to predict clinical outcome concerns the reliability of results, which are semiquantitative. Such drawbacks can be overcome easily by use of computerised image analysis systems, which give objective and reproducible results. ${ }^{12133536}$ Quantitative immunocytochemistry is carried out in our department for routine characterisation of invasive breast cancers. The information provided is used in conjunction with traditional staging systems in patient management.

In conclusion, the MIB-1 proliferation index is a reliable, practical and useful method of measuring proliferative activity and is an important predictor of clinical behaviour. It may also be useful in selecting patients with node negative breast cancer who might benefit from adjuvant treatment.

The authors wish thank Mrs Fernanda Mora and Mrs Daniela Nardo for excellent technical assistance.

This study was supported by the special project, A.C.R.O., of the Italian National Research Council (Grant no. 2/192/155) and by Ministero dell' Università e della Ricerca Scientifica Tecnologica, Italy.

Brown DC, Gatter KC. Monoclonal antibody Ki-67: its use in histopathology. Histopathology 1990;17:489-503.

2 Gerdes J. Ki-67 and other proliferation markers useful for immunohistological diagnostic and prognostic evaluations immunohistological diagnostic and prognostic evaluation

in human malignancies. Semin Cancer Biol 1990;1:199-206.

3 Cattoretti G, Becker MHG, Key G, Duchrou M, Schlter C, Galle J, et al. Monoclonal antibodies against recombinant parts of the $\mathrm{Ki}-67$ antigen (MIB 1 and MIB 3) detect proliferating cells in microwave-processed formalin-fixed paraffin sections. F Pathol 1992;168:357-63.

4 Key G, Becker MHG, Baron B, Duchrow M, Schluter C, Flad HD, et al. New Ki-67-equivalent murine monoclonal antibodies (MIB 1-3) generated against bacterially expressed part of the Ki-67 cDNA containing three 62 base pressed part of the Ki-67 cDNA containing three 62 base pair repetitive elements enco

5 Key G, Becker MHG, Duchrow M, Scluter C, Gerdes J. New KI-67 equivalent murine monoclonal antibodies (MIB 1-3) prepared against recombinant parts of the KI-67 antigen. Anal Cell Pathol 1992;4:181-3.

6 McCormick D, Chong H, Hobbs C, Datta C, Hall PA. Detection of the $\mathrm{Ki}-67$ antigen in fixed and wax-embedded sections with the monoclonal antibody MIB 1 . Histopathology 1993;22:355-60.

7 Hall PA, Levison DA. Assessment of cell proliferation in histological material. $\mathcal{f}$ Clin Pathol 1990;43:184-92.

8 Hall PA Levison DA Woods AL, Yu CC, Kellock DB, Watkins JA, et al. Proliferating cell nuclear antigen (PCNA) immunolocalization in paraffin sections: an index of cell $\mathrm{N}$ proliferation with evidence of deregulated expression in some neoplasms. F Pathol 1990;162:285-94.

9 Morris ES, Elston CW, Bell JA, Galea M, Blamey RW, Ellis O IO. An evaluation of the cell cycle-associated monoclonal antibody $\mathrm{Ki}-\mathrm{S} 1$ as a prognostic factor in primary invasive $\sigma$ adenocarcinoma of the breast. $\mathcal{F}$ Pathol 1995; 176:55-62.

10 Sampson SA, Kreipe H, Gillett CE, Smith P, Chaudary $\bullet$ MA, Khan A, et al. KiS1 - a novel monoclonal antibody which recognizes proliferating cells: evaluation of its $\mathbb{D}$ which recognizes proliferating cells: evaluation of its relationship to prognct

11 Hermanek P, Sobin LH. UICC TNM Classification of malignant tumors. 4 th edn, 2 nd revision. Berlin: SpringerVerlag, 1992

12 Querzoli P, Ferretti S, Albonico G, Magri E, Scapoli D, Indelli $M$, et al. Application of quantitative analysis to biologic profile evaluation in breast cancer. Cancer 1995;76: 2510-17.

13 Baddoura FK, Cohen C, Unger ER, DeRose PB, Chenggis $M$. Image analysis for quantitation of estrogen receptor in formalin-fixed paraffin-embedded sections of breast carciformalin-fixed paraffin-embedded

14 Linden MD, Torres FX, Kubus J, Zarbo RJ. Clinical application of morphologic and immunocytochemical assess-
ments of cell proliferation. Am $f$ Clin Pathol 1992; ments of cell pro

15 Esteban JM, Chul A, Battifora H, Felder B. Predictive value of estrogen receptors evaluated by quantitative immunohistochemical analysis in breast cancer. Am $\mathcal{f}$ Clin Pathol 1994;102:9-12.

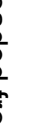


16 Silvestrini R, Benini E, Daidone MG, Veneroni S, Boracchi $\mathrm{P}$, Cappelletti V, et al. P53 as an independent prognostic marker in lymph node-negative breast cancer patients. $\mathcal{f}$ Natl Cancer Inst 1993;85:965-70.

17 Lee E, Desu M. A computer program for comparing k samples with right censored data. Comp Progr Biomed 1972;2:315-21.

18 Marchetti E, Querzoli P, Marzola A, Bagni A, Ferretti S, Fabris G, et al Assessment of proliferative rate of breast cancer by Ki-67 monoclonal antibody. Mod Pathol 1990;3: cancer

19 Querzoli P, Marchetti E, Ferretti S, Albonico G, Orvieto E, Tassinari D, et al. Contribution of cell kinetics with Ki-67 to the biopathological and prognostic characterization of breast cancer. Int $\mathcal{F}$ Biol Markers 1993;8:38.

20 Hall PA, Woods AL. Immunohistochemical markers of cellular proliferation: achievements, problems and prospects. Cell Tissue Kinet 1990;23:505-22.

21 Quinn CM, Wright NA. The clinical assessment of proliferation and growth in human tumours: evaluation as proliferation and growth in human tumours: ev
prognostic variables. $\mathcal{F}$ Pathol 1990;160:93-102.

22 Silvestrini R on behalf of the SICCAB Group for Quality Control of Cell Kinetic Determination. Feasibility and reproducibility of the $\left[{ }^{3} \mathrm{H}\right]$-thymidyne labelling index in breast cancer. Cell Prolif 1991;24:437-45.

23 Fonatsch C, Duchrow M, Rieder H, Schulter C, Gerdes J. Assignment of the human $\mathrm{Ki}-67$ gene (MKI67) to 10q25qter. Genomics 1991;11:476-77.

24 Gerdes J, Schlueter L, Duchrow M, Wohlenberg C, Gerlach C, Stahmer I, et al. Immunobiochemical and molecular biologic characterization of the cell proliferation-associated nuclear antigen that is defined by monoclonal antibody nuclear antigen that is defined by m

25 Sahin AA, Ro J, Ro JY, Blick MB, El-Naggar AK, Ordonez NG, et al. $\mathrm{Ki}-67$ immunostaining in node-negative stage I-II breast carcinoma. Cancer 1991;68:549-57.

26 Veronese SM, Gambacorta M. Detection of KI-67 proliferation rate in breast cancer. Correlation with clinical and pathological features. Am $\mathcal{F}$ Clin Pathol 1991;95:30-4.
27 Veronese SM, Gambacorta M, Gottardi O, Scanzi F, Ferrari $M$, Lampertico P. Proliferation index as a prognostic marker in breast cancer. Cancer 1993;71:3926-31.

28 Barbareschi M, Girlando S, Mauri FM, Forti S, Eccher C, Mauri FA, et al. Quantitative growth fraction evaluation with MIBI and $\mathrm{Ki}-67$ antibodies in breast carcinomas. $\mathrm{Am}$ f Clin Pathol 1994;102:171-5.

29 Kerns BJM, Jordan PA, Faerman LL, Berchuck A, Bast RC Layfield LJ. Determination of proliferation index with MIB-1 in advanced ovarian cancer using quantitative MIB-1 in advanced ovarian cancer using quan

30 Onda K, Davis RL, Shibuya M, Wilson CB, Hoshino T. Correlation between the bromodeoxyuridine labeling index and the MIB-1 and $\mathrm{Ki}-67$ proliferating cell indices in cerebral gliomas. Cancer 1994;74:1921-6.

31 Pinder SE, Wencyk P, Sibbering DM, Bell JA, Elston CW, Nicholson $\mathrm{R}$, et al. Assessment of the new proliferation marker MIB-1 in breast carcinoma using image analysis: associations with other prognostic factors and survival. $\mathrm{Br} \mathcal{F}$ Cancer 1995;71:146-9.

32 Keshgegian AA, Cnaan A. Proliferation markers in breast carcinoma. Mitotic figure count, $\mathrm{S}$-phase fraction, proliferating cell nuclear antigen, $\mathrm{Ki}-67$ and MIB-1. Am $\mathrm{f}$ Clin ating cell nuclear antigen
Pathol 1995;104:42-9.

33 Leong ASY, Vinyuvat S, Suthipintawong C, Milios J. A comparative study of cell proliferation markers in breast carcinomas. F Clin Pathol: Mol Pathol 1995;48:M83-7.

34 Jensen V, Ladekarl $M$, Holm-Nielsen P, Melsen F, Soerensen FB. The prognostic value of oncogenic antigen $519(\mathrm{OA}-519)$ expression and proliferative activity detected by antibody MIB-1 in node negative breast cancer. $\mathcal{F}$ Pathol 1995;176:343-52.

35 Bacus JW, Grace LJ. An optical microscope system of standardized cell measurements and analysis. Applied Optics 1987;16:3280-93.

36 Bacus SS, Goldschmidt R, Chin D, Moran G, Weimberg D, Bacus JW. Biological grading of breast cancer using antibodies to proliferating cells and other markers. $A m \mathcal{F}$ Pathol 1989;135:783-92. 